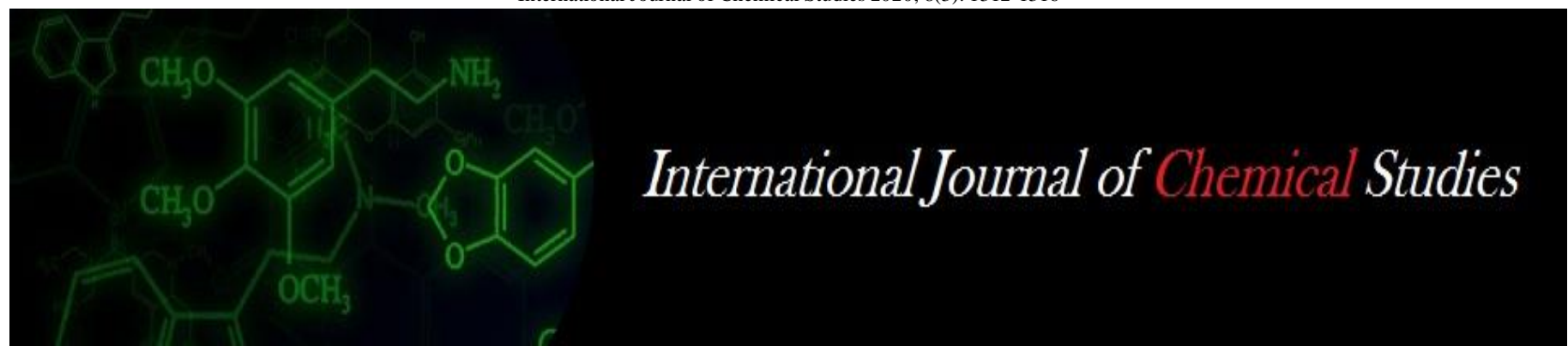

P-ISSN: 2349-8528

E-ISSN: 2321-4902

www.chemijournal.com

IJCS 2020; 8(3): 1312-1316

(C) 2020 IJCS

Received: 08-03-2020

Accepted: 10-04-2020

V Sravani

Ph.D. (Hort.), Department of

Vegetable Science, NAU,

Navsari, Gujarat, India

\section{SN Saravaiya}

Ph.D. (Hort.), Department of Vegetable Science, NAU,

Navsari, Gujarat, India

\section{BN Patel}

Ph.D. (Hort.), Department of Vegetable Science, NAU,

Navsari, Gujarat, India

\section{HN Chhatrola}

Ph.D. (Hort.), Department of

Vegetable Science, NAU,

Navsari, Gujarat, India

Himani B Patel

Ph.D. (Hort.), Department of

Vegetable Science, NAU,

Navsari, Gujarat, India

JM Vashi

Ph.D. (Hort.), Department of Vegetable Science, NAU,

Navsari, Gujarat, India
Corresponding Author:

V Sravani

Ph.D. (Hort.), Department of

Vegetable Science, NAU,

Navsari, Gujarat, India

\section{Response of plant bioregulators on growth parameters and plant growth analysis of onion (Allium cepa L.)}

\section{Sravani, SN Saravaiya, BN Patel, HN Chhatrola, Himani B Patel and JM Vashi}

DOI: https://doi.org/10.22271/chemi.2020.v8.i3r.9380

\begin{abstract}
The experiment was carried out with a view to study the response of plant bioregulators on growth parameters and plant growth analysis of onion at Regional Horticultural Research Station of Navsari Agricultural University, Navsari (Gujarat) during Rabi 2018 and 2019. The number of leaves per plant at 45 DATP (7.92), 60 DATP (8.75) and 90 DATP (9.42) and days to maturity (129.17) were found significant on pooled analysis basis under the treatment $\mathrm{T}_{1}\left(\mathrm{GA}_{3} 25 \mathrm{mg} \mathrm{l}^{-1}\right)$. Among physiological parameters, treatment $\mathrm{T}_{1}\left(\mathrm{GA}_{3} 25 \mathrm{mg} \mathrm{l}^{-1}\right)$ found best for leaf area index at 60 DATP (2.85), as well as harvest index (93.72) in pooled analysis. Crop growth rate at 60-90 DATP $\left(5.11 \mathrm{~g} \mathrm{~m}^{-2}\right.$ day $\left.^{-1}\right)$ with $\mathrm{T}_{3}$ $\left(\mathrm{GA}_{3} 75 \mathrm{mg} \mathrm{l}^{-1}\right)$, net assimilation rate at 60-90 DATP $\left(0.107 \mathrm{~g} \mathrm{~cm}^{-2} \mathrm{day}^{-1}\right)$ with $\mathrm{T}_{8}\left(\mathrm{GA}_{3} 25 \mathrm{mg} \mathrm{l}^{-1}+\mathrm{NAA}\right.$

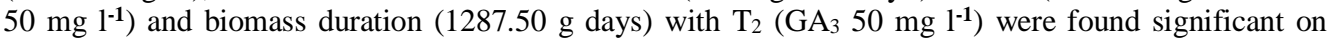
pooled analysis basis.
\end{abstract}

Keywords: Plant bioregulators, NAA, $\mathrm{GA}_{3}$, growth and plant growth analysis

\section{Introduction}

India is the world's second largest producer of vegetables (187.47 million tonnes) next only to China (Anonymous, 2019). Onion (Allium cepa L.) is an important and indispensable item in every kitchen as condiment cum vegetable in India. It is one of the important underground bulbous vegetable crops of Alliaceae family and is said to be native of Central Asia and Mediterranean region (Mc Collum, 1976) ${ }^{[8]}$. Plant growth regulators are organic compounds other than nutrients which in small amount promotes / inhibit or otherwise modify any physiological response in plant (Purohit, 2007) ${ }^{[16]}$. Plant bioregulators called as magic chemicals are new generation agrochemicals, when added in small quantity, modify the natural growth regulatory systems right from seed germination to senescence in several vegetable crops and also regulate and modify various physiological processes within the plant and they help to increase the yield (Weaver, 1972) ${ }^{[33]}$.

\section{Materials and methods}

The field experiment was carried out at the vegetable research scheme, Regional Horticultural Research Station of the Navsari Agricultural University, Navsari, Gujarat, India during Rabi 2018 and 2019 on cv. Gujarat Junagadh Red Onion 11 to investigate the response of plant bioregulators on growth parameters and plant growth analysis of onion. The experiment was conducted in Randomized Block Design (RBD) with three replications, which included 12 treatments namely, $\mathrm{T}_{1}$ : GA $25 \mathrm{mg} \mathrm{l}^{-1}, \mathrm{~T}_{2}$ : $\mathrm{GA}_{3} 50 \mathrm{mg} \mathrm{l}^{-1}, \mathrm{~T}_{3}$ : GA $35 \mathrm{mg} \mathrm{l}^{-1}, \mathrm{~T}_{4}$ : NAA $25 \mathrm{mg} \mathrm{l}^{-}$ ${ }^{1}, \mathrm{~T}_{5}$ : NAA $50 \mathrm{mg} \mathrm{l}^{-1}, \mathrm{~T}_{6}$ : NAA $75 \mathrm{mg} \mathrm{l}^{-1}, \mathrm{~T}_{7}$ : GA $25 \mathrm{mg} \mathrm{l}^{-1}+\mathrm{NAA}_{2} 25 \mathrm{mg} \mathrm{l}^{-1}, \mathrm{~T}_{8}$ : GA $25 \mathrm{mg}$ $\mathrm{l}^{-1}+\mathrm{NAA} 50 \mathrm{mg} \mathrm{l}^{-1}, \mathrm{~T}_{9}: \mathrm{GA}_{3} 25 \mathrm{mg} \mathrm{l}^{-1}+\mathrm{NAA} 75 \mathrm{mg} \mathrm{l}^{-1}, \mathrm{~T}_{10}: \mathrm{GA}_{3} 50 \mathrm{mg} \mathrm{l}^{-1}+\mathrm{NAA} 50 \mathrm{mg} \mathrm{l}^{-1}$, $\mathrm{T}_{11}$ : $\mathrm{GA}_{3} 75 \mathrm{mg} \mathrm{l}^{-1}+\mathrm{NAA} 75 \mathrm{mg} \mathrm{l}^{-1}$ and $\mathrm{T}_{12}$ : Control. The foliar sprays were made at 30 days after transplanting during morning hours to avoid the dehydration effect. For recording different observations, ten plants of onion from each net plot area were selected randomly and tagged with labels. 


\section{Results and discussion}

The data revealed that the plant height was significantly influenced by different treatments under both the years and showed non-significant under pooled analysis (Table 1). The highest plant height was obtained under the treatment of $\mathrm{T}_{1}$ $\left(\mathrm{GA}_{3} 25 \mathrm{mg} \mathrm{l^{-1 }}\right)$ might be due to increasing cell wall extensibility by $\mathrm{GA}_{3}$. The exogenously applied GA might have activated the endogenous hormonal activates which ultimately led to leaf elongation in onion plant. It was also reported that $\mathrm{GA}_{3}$ increasing plasticity of cell wall followed by hydrolysis of starch to sugars which lowers the water potential of cell, resulting in the entry of water into the cell causing elongation. Similar findings were reported for onion (Saleh and Abed, 1989; Sharma et al., 1998; Tiwari et al., 2003; Suseela et al., 2005; Singh, 2006; Islam et al., 2007; Rashid, 2010; Ouzounidu et al., 2011; Nagwa et al., 2013; Omesh et al., 2018) ${ }^{[20,24,31,5,18,9,13]}$ and for garlic (Singh et al., 2014; Govind et al., 2015) ${ }^{[27,2]}$.

Table 1: Effect of different treatments on plant height $(\mathrm{cm})$ at 45, 60 and 90 DATP of onion

\begin{tabular}{|c|c|c|c|c|c|c|c|c|c|}
\hline \multirow{3}{*}{ Treatments } & \multicolumn{9}{|c|}{ Plant height (cm) } \\
\hline & \multicolumn{3}{|c|}{45 DATP } & \multicolumn{3}{|c|}{ 60 DATP } & \multicolumn{3}{|c|}{90 DATP } \\
\hline & 2018 & 2019 & Pooled & 2018 & 2019 & Pooled & 2018 & 2019 & Pooled \\
\hline $\mathrm{T}_{1}: \mathrm{GA}_{3} 25 \mathrm{mg} \mathrm{l}^{-1}$ & 58.23 & 67.24 & 62.73 & 63.88 & 78.07 & 70.98 & 67.10 & 80.56 & 73.83 \\
\hline $\mathrm{T}_{2}: \mathrm{GA}_{3} 50 \mathrm{mg} \mathrm{l}^{-1}$ & 60.72 & 66.78 & 63.75 & 64.53 & 77.10 & 70.81 & 67.56 & 79.66 & 73.61 \\
\hline $\mathrm{T}_{3}: \mathrm{GA}_{3} 75 \mathrm{mg} \mathrm{l}^{-1}$ & 59.40 & 65.12 & 62.26 & 63.23 & 75.79 & 69.51 & 65.93 & 79.28 & 72.61 \\
\hline $\mathrm{T}_{4}:$ NAA $25 \mathrm{mg} \mathrm{l}^{-1}$ & 61.98 & 64.92 & 63.44 & 64.95 & 73.25 & 69.10 & 66.76 & 76.54 & 71.65 \\
\hline $\mathrm{T}_{5}$ : NAA $50 \mathrm{mg} \mathrm{l}^{-1}$ & 62.59 & 66.18 & 64.39 & 64.53 & 74.78 & 69.66 & 67.59 & 76.91 & 72.25 \\
\hline $\mathrm{T}_{6}:$ NAA $75 \mathrm{mg} \mathrm{l}^{-1}$ & 62.06 & 65.24 & 63.65 & 64.11 & 72.54 & 68.33 & 67.43 & 75.60 & 71.52 \\
\hline $\mathrm{T}_{7}: \mathrm{GA}_{3} 25 \mathrm{mg} \mathrm{l}^{-1}+\mathrm{NAA} 25 \mathrm{mg} \mathrm{l}^{-1}$ & 58.28 & 61.90 & 60.09 & 63.62 & 68.71 & 66.16 & 67.81 & 71.24 & 69.53 \\
\hline $\mathrm{T}_{8}: \mathrm{GA}_{3} 25 \mathrm{mg} \mathrm{l}^{-1}+\mathrm{NAA} 50 \mathrm{mg} \mathrm{l}^{-1}$ & 63.11 & 64.16 & 63.64 & 66.16 & 73.41 & 69.78 & 70.20 & 77.15 & 73.67 \\
\hline $\mathrm{T}_{9}: \mathrm{GA}_{3} 25 \mathrm{mg} \mathrm{l}^{-1}+\mathrm{NAA} 75 \mathrm{mg} \mathrm{l}^{-1}$ & 60.34 & 67.18 & 63.76 & 62.96 & 74.85 & 68.91 & 65.20 & 77.40 & 71.30 \\
\hline $\mathrm{T}_{10}: \mathrm{GA}_{3} 50 \mathrm{mg} \mathrm{l}^{-1}+\mathrm{NAA} 50 \mathrm{mg} \mathrm{l}^{-1}$ & 62.10 & 64.83 & 63.47 & 65.29 & 73.05 & 69.17 & 70.43 & 75.96 & 73.20 \\
\hline $\mathrm{T}_{11}: \mathrm{GA}_{3} 75 \mathrm{mg} \mathrm{l}^{-1}+\mathrm{NAA} 75 \mathrm{mg} \mathrm{l}^{-1}$ & 57.48 & 66.27 & 61.88 & 61.68 & 76.99 & 69.34 & 65.46 & 79.31 & 72.39 \\
\hline $\mathrm{T}_{12}:$ Control & 59.80 & 63.82 & 61.81 & 62.09 & 70.83 & 66.46 & 65.21 & 74.99 & 70.10 \\
\hline Year Mean & 60.51 & 65.30 & 62.91 & 63.92 & 74.11 & 69.01 & 67.22 & 77.05 & 72.14 \\
\hline S. Em. \pm & 1.07 & 1.03 & 1.24 & 0.80 & 1.21 & 1.55 & 1.45 & 1.12 & 1.67 \\
\hline C.D. at $5 \%$ & 3.15 & 3.02 & NS & 2.36 & 3.55 & NS & NS & 3.28 & NS \\
\hline C.V. \% & 3.08 & 2.73 & 2.90 & 2.18 & 2.83 & 1.03 & 3.75 & 2.51 & 3.12 \\
\hline \multicolumn{3}{|l|}{ YT: S. Em. \pm} & 1.05 & & & 2.93 & & & 1.30 \\
\hline YT: C. D. at $5 \%$ & & & 3.00 & & & 2.58 & & & 3.70 \\
\hline
\end{tabular}

Results related to the mean number of leaves plant ${ }^{-1}$ at 45, 60 and 90 DATP of onion as affected by various treatments are provided in Table 2 . The results of the pooled analysis of data indicated that the application of $\mathrm{GA}_{3} 25 \mathrm{mg} \mathrm{l}^{-1}\left(\mathrm{~T}_{1}\right)$ recorded the maximum number of leaves plant ${ }^{-1}$ (7.92) and was at par with the treatment $\mathrm{T}_{11}$ only. At 60 DATP, application of $\mathrm{GA}_{3}$ $25 \mathrm{mg} \mathrm{l}^{-1}\left(\mathrm{~T}_{1}\right)$ recorded maximum number of leaves plant ${ }^{-1}$ (8.75) and was at par with the treatment $\mathrm{T}_{8}$ and $\mathrm{T}_{11}$. At 90 DATP, the application of $\mathrm{GA}_{3} 25 \mathrm{mg} \mathrm{l}^{-1}\left(\mathrm{~T}_{1}\right)$ recorded the maximum number of leaves plant ${ }^{-1}(9.42)$ and was at par with the treatments $T_{11}$ and $T_{8}$. The interaction of year $\times$ treatment was found non-significant.

The increase in number of leaves per plant is mainly due to enhanced cell elongation and cell division. It enhanced the photosynthesis, respiration and catalyse activities in plant, hence enhanced the number of leaves per plant. The increase in leaf number due to application of $\mathrm{GA}_{3}$ was also reported earlier in onion (Singh et al., 1983; Shishido and Saito, 1984; Salah et al., 1989; Shakhda and Gajipara, 1998; Hye et al., 2002, Shaikh et al., 2002; Subimal et al., 2003; Tiwari et al., 2003; Suseela et al., 2005; Patel et al., 2010;) [26, 25, 20, 23, 22, 29, 4, 31 30], tomato (Gupta and Gupta, 2000; Rai et al., 2006; Nibhavanti et al., 2006) ${ }^{[3,17,10]}$ and garlic (Singh et al., 2014; Govind et al., 2015) ${ }^{[27,2]}$. The plant height and number of leaves per plant linearly increased up to the maximum vegetative growth and thereafter decreased possibly due to the senescence and drying up of tip of the leaves.

Table 2: Effect of different treatments on number of leaves plant ${ }^{-1}$ at 45, 60 and 90 DATP of onion

\begin{tabular}{|c|c|c|c|c|c|c|c|c|c|}
\hline \multirow{3}{*}{ Treatments } & \multicolumn{9}{|c|}{ Number of leaves plant ${ }^{-1}$} \\
\hline & \multicolumn{3}{|c|}{45 DATP } & \multicolumn{3}{|c|}{ 60 DATP } & \multicolumn{3}{|c|}{90 DATP } \\
\hline & 2018 & 2019 & Pooled & 2018 & 2019 & Pooled & 2018 & 2019 & Pooled \\
\hline $\mathrm{T}_{1}: \mathrm{GA}_{3} 25 \mathrm{mg} \mathrm{l}^{-1}$ & 7.67 & 8.17 & 7.92 & 8.20 & 9.30 & 8.75 & 9.07 & 9.77 & 9.42 \\
\hline $\mathrm{T}_{2}: \mathrm{GA}_{3} 50 \mathrm{mg} \mathrm{l}^{-1}$ & 6.90 & 7.87 & 7.38 & 7.77 & 8.30 & 8.03 & 8.73 & 8.77 & 8.75 \\
\hline $\mathrm{T}_{3}: \mathrm{GA}_{3} 75 \mathrm{mg} \mathrm{l}^{-1}$ & 7.03 & 7.87 & 7.45 & 7.63 & 8.93 & 8.28 & 8.10 & 9.33 & 8.72 \\
\hline 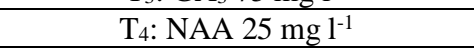 & 7.16 & 7.60 & 7.38 & 7.37 & 8.20 & 7.78 & 8.43 & 8.70 & 8.57 \\
\hline $\mathrm{T}_{5}$ : NAA $50 \mathrm{mg} \mathrm{l}^{-1}$ & 6.80 & 7.30 & 7.05 & 7.20 & 8.63 & 7.92 & 8.53 & 9.03 & 8.78 \\
\hline $\mathrm{T}_{6}:$ NAA $75 \mathrm{mg} \mathrm{l}^{-1}$ & 6.90 & 7.63 & 7.27 & 7.40 & 8.50 & 7.95 & 8.43 & 9.00 & 8.72 \\
\hline $\mathrm{T}_{7}: \mathrm{GA}_{3} 25 \mathrm{mg} \mathrm{l}^{-1}+\mathrm{NAA} 25 \mathrm{mg} \mathrm{l}^{-1}$ & 6.73 & 7.40 & 7.07 & 7.67 & 8.47 & 8.07 & 8.40 & 8.67 & 8.53 \\
\hline $\mathrm{T}_{8}: \mathrm{GA}_{3} 25 \mathrm{mg} \mathrm{l}^{-1}+\mathrm{NAA} 50 \mathrm{mg} \mathrm{l}^{-1}$ & 6.57 & 7.53 & 7.05 & 7.83 & 9.20 & 8.52 & 8.53 & 9.73 & 9.13 \\
\hline $\mathrm{T}_{9}: \mathrm{GA}_{3} 25 \mathrm{mg} \mathrm{l}^{-1}+\mathrm{NAA} 75 \mathrm{mg} \mathrm{l}^{-1}$ & 6.77 & 7.93 & 7.35 & 7.50 & 8.90 & 8.20 & 8.10 & 9.30 & 8.70 \\
\hline $\mathrm{T}_{10}: \mathrm{GA}_{3} 50 \mathrm{mg} \mathrm{l}^{-1}+\mathrm{NAA} 50 \mathrm{mg} \mathrm{l}^{-1}$ & 7.03 & 8.03 & 7.53 & 7.63 & 8.90 & 8.27 & 8.33 & 9.30 & 8.82 \\
\hline $\mathrm{T}_{11}: \mathrm{GA}_{3} 75 \mathrm{mg} \mathrm{l}^{-1}+\mathrm{NAA} 75 \mathrm{mg} \mathrm{l}^{-1}$ & 7.43 & 8.03 & 7.73 & 8.03 & 8.99 & 8.51 & 8.97 & 9.47 & 9.22 \\
\hline $\mathrm{T}_{12}:$ Control & 6.60 & 7.70 & 7.15 & 7.53 & 8.37 & 7.95 & 7.87 & 9.07 & 8.47 \\
\hline Year Mean & 6.97 & 7.76 & 7.36 & 7.65 & 8.72 & 8.19 & 8.46 & 9.18 & 8.82 \\
\hline S. Em. \pm & 0.22 & 0.17 & 0.14 & 0.18 & 0.24 & 0.15 & 0.23 & 0.25 & 0.18 \\
\hline
\end{tabular}




\begin{tabular}{|c|c|c|c|c|c|c|c|c|c|}
\hline C.D. at 5\% & 0.64 & 0.50 & 0.38 & 0.54 & 0.71 & 0.42 & 0.68 & 0.72 & 0.51 \\
\hline C.V.\% & 5.41 & 3.78 & 4.59 & 4.16 & 4.78 & 4.53 & 4.75 & 4.65 & 4.70 \\
\hline YT: S. Em. \pm & & 0.20 & & & 0.21 & & 0.24 \\
\hline YT: C. D. at 5\% NS & & & & NS & \multicolumn{3}{c|}{ NS } \\
\hline
\end{tabular}

The data pertaining to days to maturity as influenced by different treatments are presented in Table 3. The results were found to be non-significant during both the seasons whereas it was found significant in pooled analysis. An analysis of pooled mean data showed that treatment $\mathrm{T}_{1}\left(\mathrm{GA}_{3} 25 \mathrm{mg} \mathrm{l}^{-1}\right)$ recorded more number of days taken to maturity (129.17) and it was at par with the treatment $\mathrm{T}_{2}\left(\mathrm{GA}_{3} 50 \mathrm{mg} \mathrm{l}^{-\mathbf{1}}\right)$. The plants under the influence of plant growth regulators recorded maximum growth in respect of height of plant, number of leaves etc. These plants treated with $\mathrm{GA}_{3} 25 \mathrm{mg} \mathrm{l}^{-1}$ required more days for their maturity. The control plants however, deprived of such growth regulators functions. Hence, attended early maturity. The results are in conformity with the findings of Singh (2006) ${ }^{[28]}$

Looking to the mean of pooled analysis, the results of leaf area index under 90 DATP showed non-significant represented in Table 3. During 60 DATP, the maximum leaf area index (2.85) was recorded with the application of $\mathrm{T}_{1}$ $\left(\mathrm{GA}_{3} 25 \mathrm{mg} \mathrm{l}^{-1}\right)$ which was significantly at par with the treatment $\mathrm{T}_{10}$. However, the values of leaf area index under different treatments were varied from 1.91 to 2.85 . Whereas, the minimum leaf area index (1.91) was observed with the treatment $\mathrm{T}_{8}$ (Table 3). $\mathrm{GA}_{3}$ induced high leaf area index was reported in onion plants. The similar results also recorded by Nirmal et al. (1994) ${ }^{[11]}$ in onion, Khan et al. (2006) ${ }^{[6]}$ in tomato and Noor et al. (2017) ${ }^{[12]}$ in french bean.

The crop growth rate under different treatments were affected by various treatments represented in Table 3. In pooled analysis, the results showed under crop growth rate was significant. The maximum crop growth rate $\left(5.11 \mathrm{~g} \mathrm{~m}^{-2}\right.$ day $\left.^{-1}\right)$ was observed with the treatment $\mathrm{T}_{3}\left(\mathrm{GA}_{3} 75 \mathrm{mg} \mathrm{l}^{-\mathbf{1}}\right)$ which was significantly at par with the treatments. The minimum crop growth rate $\left(2.68 \mathrm{~g} \mathrm{~m}^{-2}\right.$ day $\left.^{-1}\right)$ was noted in $\mathrm{T}_{4}$ (NAA 25 $\left.\mathrm{mg} \mathrm{l}^{-1}\right)$. The interaction of year $\times$ treatment was found nonsignificant. Whereas, for crop growth rate similar results were observed with Noor et al. (2017) ${ }^{[12]}$ in French bean, Vishal et al. (2016) ${ }^{[32]}$ in strawberry and Sarkar et al. (2002) ${ }^{[21]}$ in soyabean.

Results related to the net assimilation rate were noticed in Table 4. Looking to the mean of pooled analysis, highest net assimilation rate $\left(0.107 \mathrm{~g} \mathrm{~cm}^{-2}\right.$ day $\left.^{-1}\right)$ was recorded with the treatment $\mathrm{T}_{8}\left(\mathrm{GA}_{3} 25 \mathrm{mg} \mathrm{l}^{-1}+\mathrm{NAA} 50 \mathrm{mg} \mathrm{l}^{-1}\right)$ followed by $\mathrm{T}_{3}$. The minimum net assimilation rate $\left(0.043 \mathrm{~g} \mathrm{~cm}^{-2}\right.$ day $\left.^{-1}\right)$ was found with $\mathrm{T}_{4}$. The interaction of year $\times$ treatment was found non-significant.

In pooled analysis, the harvest index of different treatments were represented in Table 4 . The significantly maximum harvest index $(93.72 \%)$ was recorded with application of $\mathrm{T}_{1}$ $\left(\mathrm{GA}_{3} 25 \mathrm{mg} \mathrm{l}^{-1}\right)$ which was significantly at par with the treatments $\mathrm{T}_{10}, \mathrm{~T}_{9}, \mathrm{~T}_{8}, \mathrm{~T}_{7}, \mathrm{~T}_{4}$ and $\mathrm{T}_{3}$. Whereas, the minimum harvest index $(86.87 \%)$ observed with $\mathrm{T}_{11}\left(\mathrm{GA}_{3} 75 \mathrm{mg} \mathrm{l}^{-1}+\right.$ NAA $\left.75 \mathrm{mg} \mathrm{l}^{-1}\right)$. The interaction of year $\times$ treatment was found non-significant. A positive influence of $\mathrm{GA}_{3}$ on harvest index was reported by Emonger (2007) in cow pea, Noor et al. (2017) ${ }^{[12]}$ in french bean and Kumar et al. (2018) ${ }^{[7]}$ in coriander.

The data related to the biomass duration of different treatments were mentioned in Table 4 . In pooled analysis, the application of $\mathrm{T}_{2}\left(\mathrm{GA}_{3} 50 \mathrm{mg} \mathrm{l}^{-1}\right)$ recorded maximum biomass duration (1287.50 $\mathrm{g}$ days) which was significantly at par with the treatments $T_{10}, T_{5}$ and $T_{7}$. Whereas, the minimum biomass duration (1114.92 $\mathrm{g}$ days) was observed with the treatment $\mathrm{T}_{12}$ (Control). The interaction of year $\times$ treatment was found non-significant.

Table 3: Effect of different treatments on days to maturity, LAI at 60 and 90 DATP and crop growth rate $\left(\mathrm{g} \mathrm{m}^{-2}\right.$ day $\left.^{-1}\right)$ at $60-90$ DATP in onion

\begin{tabular}{|c|c|c|c|c|c|c|c|c|c|c|c|c|}
\hline \multirow{3}{*}{ Treatments } & & & & \multicolumn{6}{|c|}{ Leaf Area Index (LAI) } & \multirow{2}{*}{\multicolumn{3}{|c|}{$\begin{array}{c}\text { Crop Growth Rate } \\
\left(\mathrm{g} \mathrm{m}^{-2} \text { day }^{-1}\right) \text { at 60-90 DATP }\end{array}$}} \\
\hline & \multicolumn{3}{|c|}{ Days to maturity } & \multicolumn{3}{|c|}{60 DATP } & \multicolumn{3}{|c|}{ 90 DATP } & & & \\
\hline & 2018 & 2019 & Pooled & 2018 & 2019 & Pooled & 2018 & 2019 & Pooled & 2018 & 2019 & Pooled \\
\hline $\mathrm{T}_{1}: \mathrm{GA}_{3} 25 \mathrm{mg} \mathrm{l}^{-1}$ & 128.67 & 129.67 & 129.17 & 2.85 & 2.84 & 2.85 & 2.48 & 3.71 & 3.09 & 4.44 & 4.33 & 4.39 \\
\hline $\mathrm{T}_{2}: \mathrm{GA}_{3} 50 \mathrm{mg} \mathrm{l}^{-1}$ & 125.67 & 126.33 & 126.00 & 2.36 & 2.42 & 2.39 & 2.79 & 3.12 & 2.95 & 5.00 & 4.89 & 4.94 \\
\hline $\mathrm{T}_{3}: \mathrm{GA}_{3} 75 \mathrm{mg} \mathrm{l}^{-1}$ & 122.33 & 121.00 & 121.67 & 2.26 & 2.38 & 2.32 & 2.89 & 3.24 & 3.06 & 4.74 & 5.48 & 5.11 \\
\hline $\mathrm{T}_{4}: \mathrm{NAA} 25 \mathrm{mg} \mathrm{l}^{-1}$ & 121.00 & 126.00 & 123.50 & 2.37 & 2.41 & 2.39 & 2.99 & 3.27 & 3.13 & 2.62 & 2.74 & 2.68 \\
\hline $\mathrm{T}_{5}$ : NAA $50 \mathrm{mg} \mathrm{l}^{-1}$ & 124.00 & 125.67 & 124.83 & 2.45 & 2.59 & 2.52 & 2.86 & 3.41 & 3.14 & 4.59 & 4.59 & 4.59 \\
\hline $\mathrm{T}_{6}:$ NAA $75 \mathrm{mg} \mathrm{l}^{-1}$ & 120.67 & 123.00 & 121.83 & 2.55 & 2.60 & 2.57 & 3.09 & 3.33 & 3.21 & 4.85 & 4.48 & 4.66 \\
\hline $\mathrm{T}_{7}: \mathrm{GA}_{3} 25 \mathrm{mg} \mathrm{l}^{-1}+\mathrm{NAA} 25 \mathrm{mg} \mathrm{l}^{-1}$ & 123.33 & 124.67 & 124.00 & 2.11 & 1.89 & 2.00 & 2.77 & 2.96 & 2.87 & 4.18 & 5.59 & 4.88 \\
\hline $\mathrm{T}_{8}: \mathrm{GA}_{3} 25 \mathrm{mg} \mathrm{l}^{-1}+\mathrm{NAA} 50 \mathrm{mg} \mathrm{l}^{-1}$ & 119.67 & 119.00 & 119.33 & 1.91 & 1.91 & 1.91 & 2.53 & 2.92 & 2.73 & 4.37 & 5.78 & 5.07 \\
\hline $\mathrm{T}_{9}: \mathrm{GA}_{3} 25 \mathrm{mg} \mathrm{l}^{-1}+\mathrm{NAA} 75 \mathrm{mg} \mathrm{l}^{-1}$ & 123.00 & 123.00 & 123.00 & 2.01 & 1.90 & 1.96 & 2.69 & 2.84 & 2.77 & 2.96 & 3.81 & 3.39 \\
\hline $\mathrm{T}_{10}: \mathrm{GA}_{3} 50 \mathrm{mg} \mathrm{l}^{-1}+\mathrm{NAA} 50 \mathrm{mg} \mathrm{l}^{-1}$ & 122.67 & 122.67 & 122.67 & 2.68 & 2.74 & 2.71 & 3.32 & 3.55 & 3.44 & 4.55 & 2.89 & 3.72 \\
\hline $\mathrm{T}_{11}: \mathrm{GA}_{3} 75 \mathrm{mg} \mathrm{l}^{-1}+\mathrm{NAA} 75 \mathrm{mg} \mathrm{l}^{-1}$ & 121.33 & 122.00 & 121.67 & 2.16 & 2.04 & 2.10 & 2.78 & 3.00 & 2.89 & 3.66 & 4.93 & 4.30 \\
\hline $\mathrm{T}_{12}:$ Control & 119.33 & 118.33 & 118.83 & 1.95 & 1.90 & 1.93 & 2.65 & 2.75 & 2.70 & 3.15 & 3.44 & 3.29 \\
\hline Year Mean & 122.64 & 123.44 & 123.04 & 2.31 & 2.30 & 2.30 & 2.82 & 3.18 & 3.00 & 4.09 & 4.41 & 4.25 \\
\hline S. Em. \pm & 1.88 & 2.16 & 1.34 & 0.12 & 0.13 & 0.08 & 0.41 & 0.16 & 0.21 & 0.44 & 0.56 & 0.37 \\
\hline C.D. at $5 \%$ & NS & NS & 3.79 & 0.35 & 0.38 & 0.23 & NS & 0.48 & NS & 1.28 & 1.64 & 1.06 \\
\hline C.V. \% & 2.66 & 3.03 & 2.85 & 8.89 & 9.67 & 9.28 & 24.89 & 8.88 & 17.84 & 18.44 & 21.99 & 20.44 \\
\hline \multicolumn{3}{|l|}{ YT: S. Em. \pm} & 2.02 & & & 0.12 & & & 0.31 & & & 0.50 \\
\hline YT: C. D. at 5\% & & & NS & & & $\mathrm{NS}$ & & & NS & & & NS \\
\hline
\end{tabular}


Table 4: Effect of different treatments on net assimilation rate $\left(\mathrm{g} \mathrm{cm}^{-2} \mathrm{day}^{-1}\right)$ at $60-90$ DATP, harvest index (\%) and biomass duration ( $\mathrm{g}$ days) in onion

\begin{tabular}{|c|c|c|c|c|c|c|c|c|c|}
\hline \multirow[t]{2}{*}{ Treatments } & \multicolumn{3}{|c|}{$\begin{array}{c}\text { Net Assimilation Rate } \\
\left(\mathrm{g} \mathrm{cm}^{-2} \text { day }^{-1}\right) \text { at 60-90 DATP }\end{array}$} & \multicolumn{3}{|c|}{ Harvest Index (\%) } & \multicolumn{3}{|c|}{ Biomass Duration (g days) } \\
\hline & 2018 & 2019 & Pooled & 2018 & 2019 & Pooled & 2018 & 2019 & Pooled \\
\hline $\mathrm{T}_{1}: \mathrm{GA}_{3} 25 \mathrm{mg} \mathrm{l}^{-1}$ & 0.060 & 0.057 & 0.059 & 91.67 & 95.77 & 93.72 & 1125.00 & 1162.50 & 1143.75 \\
\hline $\mathrm{T}_{2}: \mathrm{GA}_{3} 50 \mathrm{mg} \mathrm{l}^{-1}$ & 0.085 & 0.078 & 0.081 & 88.60 & 88.81 & 88.70 & 1227.50 & 1347.50 & 1287.50 \\
\hline $\mathrm{T}_{3}: \mathrm{GA}_{3} 75 \mathrm{mg} \mathrm{l}^{-1}$ & 0.083 & 0.086 & 0.085 & 84.05 & 91.64 & 87.84 & 1200.00 & 1220.00 & 1210.00 \\
\hline 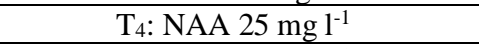 & 0.043 & 0.042 & 0.043 & 88.39 & 92.61 & 90.50 & 1192.50 & 1155.00 & 1173.75 \\
\hline $\mathrm{T}_{5}$ : NAA $50 \mathrm{mg} \mathrm{l}^{-1}$ & 0.069 & 0.066 & 0.068 & 87.92 & 90.78 & 89.35 & 1245.00 & 1260.00 & 1252.50 \\
\hline T6: $_{6}$ NAA $75 \mathrm{mg} \mathrm{l}^{-1}$ & 0.075 & 0.066 & 0.071 & 87.77 & 92.65 & 90.21 & 1167.50 & 1147.50 & 1157.50 \\
\hline $\mathrm{T}_{7}: \mathrm{GA}_{3} 25 \mathrm{mg} \mathrm{l}^{-1}+\mathrm{NAA} 25 \mathrm{mg} \mathrm{l}^{-1}$ & 0.069 & 0.103 & 0.086 & 89.89 & 92.25 & 91.07 & 1257.50 & 1222.50 & 1240.00 \\
\hline $\mathrm{T}_{8}: \mathrm{GA}_{3} 25 \mathrm{mg} \mathrm{l}^{-1}+\mathrm{NAA} 50 \mathrm{mg} \mathrm{l}^{-1}$ & 0.107 & 0.107 & 0.107 & 88.82 & 93.55 & 91.18 & 1130.00 & 1147.50 & 1138.75 \\
\hline $\mathrm{T}_{9}: \mathrm{GA}_{3} 25 \mathrm{mg} \mathrm{l}^{-1}+\mathrm{NAA} 75 \mathrm{mg} \mathrm{l}^{-1}$ & 0.057 & 0.071 & 0.064 & 90.05 & 92.59 & 91.72 & 1160.00 & 1172.50 & 1166.25 \\
\hline $\mathrm{T}_{10}: \mathrm{GA}_{3} 50 \mathrm{mg} \mathrm{l}^{-1}+\mathrm{NAA} 50 \mathrm{mg} \mathrm{l}^{-1}$ & 0.066 & 0.040 & 0.053 & 90.91 & 93.61 & 92.26 & 1267.50 & 1275.00 & 1271.25 \\
\hline $\mathrm{T}_{11}: \mathrm{GA}_{3} 75 \mathrm{mg} \mathrm{l}^{-1}+\mathrm{NAA} 75 \mathrm{mg} \mathrm{l}^{-1}$ & 0.076 & 0.086 & 0.081 & 83.91 & 89.84 & 86.87 & 1227.50 & 1197.50 & 1212.50 \\
\hline $\mathrm{T}_{12}:$ Control & 0.058 & 0.070 & 0.064 & 89.23 & 86.31 & 87.77 & 1132.50 & 1097.33 & 1114.92 \\
\hline Year Mean & 0.071 & 0.073 & 0.071 & 88.50 & 91.70 & 90.10 & 1194.38 & 1200.40 & 1197.39 \\
\hline S. Em. \pm & 0.007 & 0.008 & 0.006 & 1.62 & 1.65 & 1.20 & 23.65 & 39.31 & 22.79 \\
\hline C.D. at $5 \%$ & 0.021 & 0.023 & 0.016 & 4.74 & 4.85 & 3.41 & 69.37 & 115.30 & 64.61 \\
\hline C.V. $\%$ & 17.76 & 18.29 & 18.04 & 3.17 & 3.12 & 3.14 & 3.43 & 5.67 & 4.69 \\
\hline \multicolumn{3}{|l|}{ YT: S. Em. \pm} & 0.008 & & & 1.64 & & & 32.44 \\
\hline \multicolumn{3}{|l|}{ YT: C. D. at $5 \%$} & NS & & & $\mathrm{NS}$ & & & NS \\
\hline
\end{tabular}

\section{Conclusion}

The effect of foliar application of $\mathrm{GA}_{3}$ and NAA on growth characters namely, plant height at 45, 60 and 90 DATP found non-significant and number of leaves per plant at 45 DATP (7.92), 60 DATP (8.75) and 90 DATP (9.42) and days to maturity (129.17) found significant on pooled analysis basis. In all the growth parameters, treatment $\mathrm{T}_{1}\left(\mathrm{GA}_{3} 25 \mathrm{mg} \mathrm{l}^{-1}\right)$ found as a best treatment. Among physiological parameters, leaf area index at 60 DATP (2.85), harvest index (93.72) was found significant on pooled analysis basis, and treatment $\mathrm{T}_{1}$ $\left(\mathrm{GA}_{3} 25 \mathrm{mg} \mathrm{l}^{-1}\right)$ found as a best treatment. Crop growth rate at 60-90 DATP $\left(5.11 \mathrm{~g} \mathrm{~m}^{-2}\right.$ day $\left.^{-1}\right)$ with $\mathrm{T}_{3}\left(\mathrm{GA}_{3} 75 \mathrm{mg} \mathrm{l}^{-1}\right)$, net assimilation rate at 60-90 DATP $\left(0.107 \mathrm{~g} \mathrm{~cm}^{-2}\right.$ day $\left.^{-1}\right)$ with $\mathrm{T}_{8}$ $\left(\mathrm{GA}_{3} 25 \mathrm{mg} \mathrm{l}^{-\mathbf{1}}+\mathrm{NAA} 50 \mathrm{mg} \mathrm{l}^{-\mathbf{1}}\right)$ and biomass duration (1287.50 $\mathrm{g}$ days) with $\mathrm{T}_{2}\left(\mathrm{GA}_{3} 50 \mathrm{mg} \mathrm{l^{-1 }}\right)$ was found significant on pooled analysis basis.

\section{References}

1. Emongor V. Gibberellic acid $\left(\mathrm{GA}_{3}\right)$ influence on vegetative growth, nodulation and yield of cowpea (Vigna unguiculata L.). Journal of Agronomy. 2007; 6:509-517.

2. Govind, Maji S, Kumawat R, Pal A, Kumar S, Saha S. Improvement of growth, yield and quality of garlic (Allium sativum L.) cv. G-282 through a novel approach. The Bioscan. 2015; 10(1):23-27.

3. Gupta PK, Gupta AK. Efficacy of plant growth regulators (IAA and NAA) and micronutrient mixture on growth, flowering, fruiting and shelf life of tomato (Solanum lycopersicum Mill.). Current Agriculture, 2000; 32(12):83-86.

4. Hye AM, Shahidul Haque M, Abdul Karim M. Influence of growth regulators and their time of application on yield of onion. Pakistan Journal of Biological Sciences. 2002; 5(10):1021-1023.

5. Islam MS, Islam MO, Alam MN, Ali MK, Rahman MA. Effect of growth regulator on growth, yield and yield components of onion. Asian Journal of plant Sciences. 2007; 6(5):849-853.

6. Khan MM, Gautam AC, Mohammad F, Siddiqui MH, Naeem M, Khan MN. Effect of gibberellic acid spray on performance of tomato. Turk Jornal of Biology. 2006; 30:11-16.

7. Kumar S, Malik TP, Tehlan SK. Effect of gibberellic acid on growth and seed yield of coriander (Coriandrum sativum L.). International Journal of Current Microbiology and Applied Sciences. 2018; 7(9):25582566.

8. Mc Collum GD. Onion and Allies. In: Simmonds, N.N. (ed.) Evolution of crop plants, Longman, London. 1976; 53:186-190.

9. Nagwa MKH, Shafeek MR, Saleh SA, Nadia HMEG. Growth, yield and nutritional values of onion (Allium cepa L.) plants as affected by bioregulators and vitamin $\mathrm{E}$ under newly reclaimed lands. Journal of Applield Sciences and Research. 2013; 9(1):795-803.

10. Nibhavanti B, Bhalekar MN, Gupta NS, Anjali D. Effect of growth regulators on growth and yield of tomato in summer. Maharashtra Journal of Agriculture. 2006; 31(1):64-65.

11. Nirmal SV, Deore BP, Patil RC. Effect of growth substances on yield and yield contributing traits in onion. Journal of Maharashtra Agricultural University. 1994; 19(1):136-137.

12. Noor F, Hossain F, Ara U. Effect of gibberellic acid $\left(\mathrm{GA}_{3}\right)$ on growth and yield parameters of French bean (Phaseolus vulgaris L.). Journal of Asiatic Society of Bangladesh Sciences. 2017; 43(1):49-60.

13. Omesh T, Vijay Kumar, Jitendra S. Pruning and gibberellic acid on the growth and yield attributes of onion (Allium cepa L.) var. Agrifound Light Red. International Journal of Current Microbiology and Applied Sciences. 2018; 7(1):976-981.

14. Ouzounidou G, Giannakoula A, Asfi M, Ilias I. Differential responses of onion and garlic against plant growth regulators. Pakistan Journal of Botany. 2007; 43(4):2051-2057.

15. Patel MJ, Patel HC, Chavda JC. Influence of plant growth regulators and their application methods on yield and quality of onion (Allium cepa L.). Asian Journal of Horticulture. 2007; 5(2):263-265.

16. Purohit SS. Growth Regulators, Plant Physiology, National Book Trust, New Delhi, 2007, 32-46. 
17. Rai N, Yadav DS, Patel KK, Yadav RK, Asat BS, Chaubey T. Effect of plant growth regulators on growth, yield and quality of tomato, (Solanum lycopersicum Mill.) grown under mid hill of Meghalaya. Vegetable Science. 2006; 33(2):180-182.

18. Rashid MHA. Effect of sulphur and $\mathrm{GA}_{3}$ on the growth and yield of onion. Progressive Agriculture. 2010; 21(12):57-63.

19. Saimbhi MS, Kanwar JS, Nandpuri KS. Hasstening of tomato ripening with foliar aprays of 2 - chloroethyl phosphonic acid. Punjab Agricultural University Journal of Research. 1976; 13:286-289.

20. Salah MMS, Abed DJ. Effect of gibberellic acid and naphthalene acetic acid on growth, yield and quality of onion. Disrat. 1989; 16:39-51.

21. Sarkar PK, Haque MS, Karim MA. Growth analysis of soybean as influenced by $\mathrm{GA}_{3}$ and IAA and their frequency of application. Journal of Agronomy. 2002; 1:123-126.

22. Shaikh AM, Vyakaranahal BS, Shekhargouda M, Dharmatti PR. Influence of bulb size and growth regulators on growth, seed yield and quality of onion $\mathrm{cv}$. Nashik Red. Seed Reearch. 2002; 30(2):223-229.

23. Shakhda VP, Gajipara NN. A note on influence of IAA, IBA and $\mathrm{GA}_{3}$ on growth and yield of onion (Allium cepa L.). Vegetable Science, 1998; 25(2):185-186.

24. Sharma N, Kaur N, Gupta AK. Effect of gibberellic acid chlorocholine chloride on tuberisation and growth of potato (Solanum tuberosum L.). Journal of science and Food Agriculture. 1998; 78(4):466-470.

25. Shishido Y, Saito T. Effect of plant growth regulators on low temperature induction of flower buds in onion plants. Journal of Japanese Society Horticultural Sciences. 1984; 53:45-51.

26. Singh AR, Pankaj SL, Singh GN. Effect of growth regulators on growth, yield and quality of onion. Punjab Horticulture Journal. 1983; 23:100-104.

27. Singh HD, Maji S, Kumar S. Influence of plant bioregulators on growth and yield of garlic (Allium sativum L.). Inernational Journal of Agricultural Sciences. 2014; 10(2):546-549.

28. Singh M. Response of growth regulators on bulb yield of onion (Allium cepa L.). International Journal of Agricultural Sciences. 2006; 2(2):589-590.

29. Subimal M, Subhadeep N, Ghanji P, Sukala N. Effect of doses of $\mathrm{GA}_{3}$ and NAA on growthand yield of onion (Allium cepa L.) cv. N-53. Environmental Ecology. 2003; 21(3):568-571.

30. Suseela T, Ravisankar C, Rao BV. Effect of growth regulators and method of application on growth and yield of onion cv. N-53. Journal of Research ANGRAU. 2005; 33(4):110-113.

31. Tiwari RS, Ankur A, Sengar SC. Effect of bioregulators on growth, bulb yield, quality and storability of onion cv. Pusa Red. Indian Journal of Plant Physiology. 2003; 8(4):411-413.

32. Vishal VC, Thippesha D, Chethana K. Mahesh GBM, Veeresha BG, Basavraj AK. Effect of various growth regulators on vegetative parameters of strawberry (Fragaria annanasa Duch.) cv. Sujatha. Research Journal of Chemistry and Environmental Sciences. 2016; 4(4):6871.

33. Weaver RJ. Plant Growth Substances in Agriculture. W. H. Freeman and Co., San Francisco, 1972, 339. 